\title{
RESPON KOMUNITAS BENTHIK INSEKTA EMPAT BULAN PASCA-KEBAKARAN HUTAN 2002 DI HULU KALI BOYONG GUNUNG MERAPI
}

\author{
Tjut Sugandawaty Djohan \\ Laboratorium Ekologi dan Konservasi \\ Fakultas Biologi Universitas Gadjah Mada \\ Email: tjutdjohan@ugm.ac.id \\ Efendi Gafur Songge, Sugotowikan, Achmad Ariefiendy Husen, \\ Rani Asmarayani, dan Wina Narulita \\ Fakultas Biologi Universitas Gadjah Mada
}

\begin{abstract}
The purpose of this research is to study the response of benthic insect community in the headwater of Boyong River, Mount Merapi, four months post-forest fire in 2002. Energy at the headwater ecosystem was based on the detritus food-chain. The presence of benthic community indicated forest health. The forest fire caused energy which entered into the river changed from allochtonous coarse particulat organic matter (CPOM) to fine particulat organic matter (FPOM). This change would be responded by the functional group of benthic community. Data were collected with Surber Sampler. The result showed that there were 12 genus constituent of benthic insects consisted of functional groups of collector gather, collector filter, predator, dan scrapper. The dominant functional groups were collector gather and collector filters, 2256 individual $/ \mathrm{m}^{3}$ or $86.02 \%$ and the dominant genus of Baetis and Leutcra. Otherwise, scrapper was founded 111 individual $/ \mathrm{m}^{3}$ or $4 \%$ and predator 256 individual $/ \mathrm{m}^{3}$ or $10 \%$. This condition showed that four months post-forest fire indicated dominant allochtonous in Boyong River was CPOM and FPOM with size of $1 \mathrm{~mm}$. The quality of nutrients in the water was low, otherwise, the sediment nutrients was high. The dominance of functional group of collectors indicated that ecosystem of headwater forest in Boyong River had not been fully recovered.
\end{abstract}

Keywords: Headwater; Catchment area; Collector functional group; Tropical rainforest

\begin{abstract}
ABSTRAK
Tujuan penelitian ini adalah mempelajari respon komunitas benthik insekta di hulu Kali Boyong Gunung Merapi empat bulan pasca-kebakaran hutan 2002. Energi ekosistem hulu sungai berbasis detritus. Kehadiran komunitas benthik tersebut menunjukkan kesehatan hutan. Kebakaran hutan menyebabkan energi yang masuk ke dalam sungai berubah dari allochtonous coarse particulat organic matter (CPOM) menjadi fine particulat organic matter (FPOM). Perubahan ini akan direspon oleh fungsional grup komunitas benthik tersebut. Data diperoleh dengan Surber Sampler. Hasil menemukan 12 genus penyusun komunitas benthik insekta terdiri dari fungsional grup collector gather, collector filter, predator, dan scrapper. Fungsional grup dominan adalah collector gather dan collector filter, 2256 individu/ $\mathrm{m}^{3}$ atau 86,02\% dan genus dominannya Baetis dan Leutcra. Sebaliknya scrapper, ditemukan 111 individu/ $\mathrm{m}^{3}$ atau $4 \%$ dan predator 256 individu $/ \mathrm{m}^{3}$ atau $10 \%$. Keadaan ini mengindikasikan bahwa empat bulan pasca-kebakaran, allochtonous dominan Kali Boyong adalah FPOM dan CPOM ukuran $1 \mathrm{~mm}$. Kualitas hara perairan rendah, sebaliknya kandungan hara sedimen tinggi. Dominasi fungsional grup collector mengindikasikan bahwa ekosistem hutan hulu Kali Boyong belum pulih.
\end{abstract}

Kata Kunci: Hulu sungai; Daerah tangkapan air; Fungsional grup collector; Hutan hujan tropika 

ARIEFIENDY HUSEN, RANI ASMARAYANI, DAN WINA NARULITA RESPON KOMUNITAS ...

\section{PENGANTAR}

Pada tahun 2002, hutan daerah tangkapan air di kawasan Turgo dan Tritis merupakan hulu Kali Boyong bagian Barat sungai terbakar karena aktivitas manusia. Jauh pada tahun 1994, hutan tersebut juga terbakar karena aktivitas erupsi dan pyroclastic flow Gunung Merapi. Kecuali aktivitas manusia, kebakaran hutan merupakan sistem ekologi Gunung Merapi (Djohan dkk. 2012). Hulu sungai merupakan ekosistem terbuka, produktivitasnya sangat tergantung pada input allochtonous detritus dan unsur hara dari hutan daerah tangkapan airnya. Input detritus antara lain berupa daun dan ranting dalam bentuk coarse particulat organic matter (CPOM) dan unsur hara berupa fine particulat organic matter (FPOM). Allochtonous tersebut merupakan sumber makanan dan energi bagi organisme yang hidup di hulu sungai (Vannote dkk. 1980; Minshall 2003; Goldman dan Horne 1994).

Kehadiran benthik insekta di hulu sungai merespon pada kesehatan hutan daerah tangkapan air. Jadi kehadiran komunitas penyusun fungsional grup: shredder (pencabik), collector gather (pengumpul), collector filter (penyaring), predator (pemangsa), dan scrapper (penyapu), mencerminkan kondisi ekosistem hutan daerah tangkapan air dalam keadaan sehat atau rusak. Bila di perairan hulu sungai ditemukan cacah individu penyusun fungsional grup shredders melimpah, maka kehadirannya mencerminkan bahwa ekosistem hutan daerah tangkapan air sehat. Sebaliknya bila fungsional collectors-nya melimpah, maka ekosistem hutan daerah tangkapan airnya dalam keadaan rusak. Oleh sebab itu, kehadiran fungsional grup benthik insekta telah digunakan untuk biomonitoring kesehatan ekosistem hutan daerah tangkapan air baik di kawasan temperate maupun untuk kawasan tropika (Vannote dkk. 1980; Minshall 2003; Mellon dkk. 2008; Djohan dkk. 2012).
Komunitas bentik insekta fungsional grup shredder adalah pemakan mikroorganisme yang mengkoloni CPOM sebagai allochtonous, baik daun maupun ranting yang berukuran lebih besar dari $1 \mathrm{~mm}$. Komunitas tersebut secara tidak langsung mencabik dan menghancurkan allochtonous berasal dari daerah tangkapan air yang masuk ke perairan hulu sungai. Komunitas collector memakan sisa metabolisme shredder. Sisa tersebut berupa FPOM berukuran lebih kecil dari $1 \mathrm{~mm}$, tetapi terkadang komunitas benthik collector juga memakan CPOM. Berdasarkan cara pengambilan makanannya, collector dipilah dalam dua grup, yaitu collector gather dan collector filter. Colector gather mencari makan dengan berpindah-pindah, sebaliknya collector filters mencari makan dengan cara menempelkan tubuhnya pada bebatuan atau sedimen, dan menyaring air yang mengandung hara sebagai makanannya. Komunitas scrapper memakan algae dan koloni mikroflora, sedangkan komunitas bentik predator memakan semuanya baik allochtonus maupun bentik insekta lainya (Ward 1992).

Vannote dkk. (1980) menyatakan bahwa dalam River continuum concept di kawasan temperate, perubahan geomorfologi sungai secara gradual dari hulu ke hilir juga akan direspon oleh perubahan komunitas biota sepanjang aliran sungai secara kontinum. Di daerah tangkapan air dengan hutan yang sehat, komunitas shredder (pencabik) mendominasi ekosistem perairan hulu sungai (headwaters), scrapper (penyapu) dan collector (pengumpul) di perairan midstream, sedangkan collector nonpredaceus di perairan hilir (large river).

Kebakaran hutan daerah tangkapan air pasca kebakaran hutan akan meningkatkan hara yang masuk ke perairan sungai sampai beberapa tahun kemudian. Hara tersebut masuk ke perairan melalui pelindihan, transformasi hara, dan volatilisasi. Dalam kolum air, nitrogen ditransformasi menjadi 
nitrat. Sebaliknya, ion fosfor melalui erosi tanah permukaan tetap terikat dengan sedimen dasar sungai. Sebaliknya, ion $\mathrm{Ca}, \mathrm{K}$ dan $\mathrm{Mg}$ berubah dalam bentuk oksida dan terakumulasi sebagai abu, sedangkan ion $\mathrm{Cu}$, $\mathrm{Fe}, \mathrm{Mn}$ dan $\mathrm{Zn}$ hilang dari ekosistem hutan melalui proses vola-tilisasi (DeBano dkk. 1998; Spencer dkk. 2003).

Pengaruh pasca-kebakaran hutan terhadap ekosistem hulu sungai bervariasi baik secara spasial maupun temporal. Pada tipe sungai ordo 1-4, perubahan komunitas benthik insekta memakan waktu 5-10 tahun. Perubahan tersebut, terutama pada hutan tangkapan air dengan kanopi terbakar lebih dari 50\%. Sebaliknya, pada hutan logging, pemulihan komunitas benthiknya lambat. Pada hutan yang terbakar, seed bank-nya masih tersedia, sebaliknya pada hutan logging semua biomasanya diangkut ke luar ekosistem, sehingga tidak ada seed bank yang tersisa untuk partumbuhan hutannya (Minshall 2003). Di pegunungan Kettel Coville National Park, dilaporkan bahwa dalam masa dua tahun pasca kebakaran hutan di hulu sungai dan hanyutannya, fungsional grup collector, Chironomidae, Baetis, dan Simuliidae, mendominasi kelompok benthik insekta (Mellon dkk. (2008).

Benthik insekta merupakan komunitas yang sangat bergantung pada suplai allochtonous dari daerah hutan tangkapan air. Kebakaran hutan hulu Kali Boyong di tahun 2002 menyebabkan perubahan bentuk allochtonous berupa hara sebagai FPOM yang masuk ke aliran kali tersebut. Keadaan ini akan direspon dengan perubahan fungsional grup komunitas benthik insekta yang terdapat di aliran kalinya. Ekosistem hutan tangkapan air Kali Boyong yang terbakar akan memberi kontribusi allochtonous FPOM dalam bentuk hara yang sangat besar ke dalam ekosistem hulu kali tersebut. Musim hujan juga memberikan pengaruh yang besar bagi kemelimpahan benthik insekta. Hal ini terkait dengan arus air dan masuknya substrat FPOM ke dalam kali dalam jumlah besar.

Berdasarkan permasalahan yang telah dibicarakan, maka dalam penelitian respon komunitas benthik pasca kebakaran hutan, penelitian ini mempertanyakan: 1) Fungsional grup apa yang utama dalam komunitas benthik tersebut? 2) Genus apa saja yang hadir dan yang paling dominan, dan bagaimana densitasnya? 3) Bagaimana kualitas air dan sedimen meliputi $\mathrm{NH}_{4}, \mathrm{NO}_{3}$, $\mathrm{PO}_{4}$, C-organik, DO, pH, alkanitas, suhu, dan kecepatan arus?

Hipotesis dari artikel ini bahwa fungsional grup dominan adalah collectors, karena allochtonous yang masuk ke sungai bukan detritus CPOM, melainkan detritus FPOM dalam bentuk hara yang diangkut oleh surface run-off. Kemelimpahan benthik insekta di Kali Boyong pasca-kebakaran pada musim hujan akan berkurang, meskipun terdapat banyak substrat yang masuk terbawa oleh air hujan dari daerah sekitar kali. Hal ini disebabkan karena pada musim hujan kecepatan arus meningkat dan menyebabkan benthik insekta hanyut bersama arus air ke daerah hilir.

\section{Metode}

Penelitian ini dilaksanakan di hulu Kali Boyong lereng selatan Gunung Merapi, Yogyakarta pada musim hujan, 16 -17 Februari 2003 (Gambar 1; Gambar 2). Lokasi penelitian merupakan daerah aliran sungai dan juga daerah aliran lahar Gunung Merapi. Kawasan hutan sekitar hulu Kali Boyong merupakan hutan yang telah dua kali terbakar. Pada tanggal 22 November 1994, hutan terbakar akibat erupsi dan pyroclastic flows Gunung Merapi, dan pada Oktober 2002 hutan tersebut terbakar akibat aktivitas manusia dan musim kemarau ekstrim yang kering. Luas hutan yang terbakar sekitar 300 hektar. Lokasi penelitian berada $\pm 1200 \mathrm{~m} \mathrm{dpl}$ (Gambar 1). 


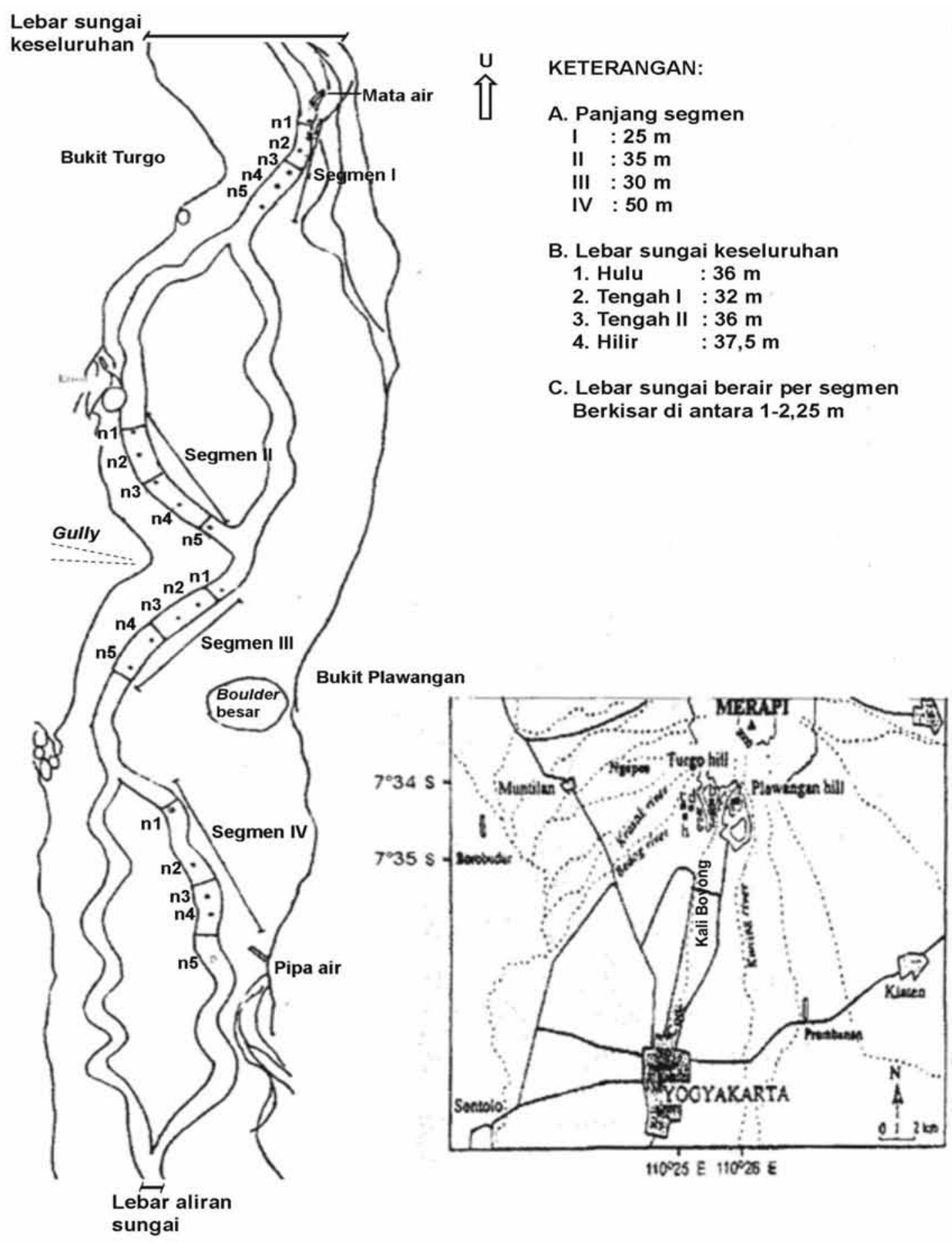

Gambar 1

Sketsa Lokasi Kajian Benthik Insekta di Hulu Kali Boyong (tidak dalam skala). Inzet: Posisi Geografis Kali Boyong

Hulu Kali Boyong mempunyai dasar perairan berbatu dan berpasir, dan juga sebagai habitat komunitas benthik insekta. Sebelum kebakaran hutan, vegetasi riparian didominasi oleh tanaman pinus, tetapi setelah kebakaran, terjadi suksesi dan vegetasi riparian yang dominan daerah ini adalah pohon kinah (Chinchnona sucirubra), puspa (Schima noronhae), dan hibiscus spp. (Djohan dan Sugotowikan 2003, data belum 
dipublikasi). Di samping itu, di sekitar kali juga terdapat banyak semak dan rumput. Demikian juga pada area aliran lahar Gunung Merapi ditemukan beberapa jenis seedling, semak, dan rumput yang tumbuh berkembang. Hal ini menggambarkan bahwa pada aliran lahar ini juga terdapat unsur hara yang terbawa oleh air hujan dari daerah tangkapan air yang kaya hara. Lebar sungai bagian hulu adalah $36 \mathrm{~m}$, tengah segmen I adalah $32 \mathrm{~m}$, tengah segmen II adalah $36 \mathrm{~m}$, sedangkan lebar hilir adalah $37,5 \mathrm{~m}$. Walaupun pada musim hujan, tetapi lebar badan sungai yang dialiri air adalah sangat sempit berkisar diantara $1-2,25 \mathrm{~m}$ dan jeluknya sekitar 10 - 14,5 cm.

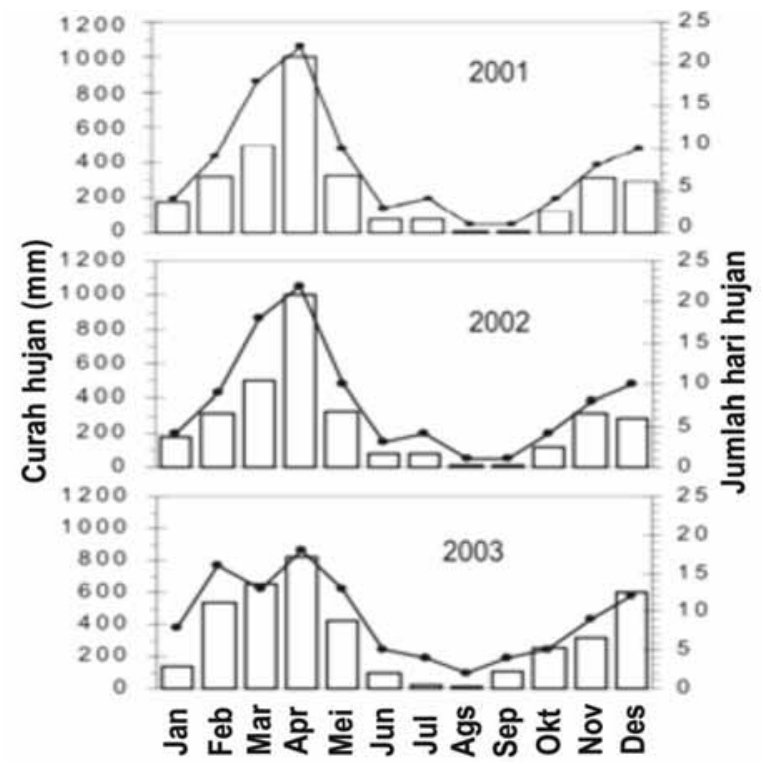

Gambar 2

Curah Hujan dan Jumlah Hari Hujan di Daerah Aliran Kali Boyong,

Gunung Merapi Tahun 2001, 2002, dan 2003

\section{Koleksi Sampel Benthik Insekta}

Pengambilan sampel dilakukan pada 4 segmen lurus sepanjang aliran kali dari arah hulu ke arah hilir secara stratified random sampling. Panjang segmen berkisar antara 25-50 m, dan jarak antar-segmen 30 - $40 \mathrm{~m}$ dengan total panjang segmen $140 \mathrm{~m}$. Pada setiap segmen, sampel benthik insekta dikoleksi dengan Surber Sampler pada setiap titik sampling, sampel dicuplik dengan ulangan 5 kali. Penentuan titik sampling berdasarkan aliran air dengan turbulensi tidak telalu besar, dan juga merupakan aliran sungai yang lurus (Gambar 1). Sampel benthik tersebut dikoleksi dengan menggunakan Surber Sampler $30 \mathrm{~cm}$ x $30 \mathrm{~cm}$ yang dibenamkan ke dasar sungai sedalam 5 $\mathrm{cm}$. Volume setiap titik sampling adalah 4500 $\mathrm{cm}^{3}$ (Wetzel dan Likens 1991).

Pengambilan sampel dimulai dari titik sampling yang letaknya paling hilir pada segmen IV ke arah hulu. Kemudian semua batu yang ada di dalam Surber tersebut dibersihkan perlahanlahan dengan menggunakan kuas agar benthik insekta yang menempel pada batu terlepas. Oleh karena gerakan aliran air, maka benthik insekta itu akan terbawa masuk dengan sendirinya ke dalam jaring Surber. Setelah selesai, sedimen yang ada di dalam Surber diaduk secara perlahan-lahan agar benthik insekta yang hidup di dalam sedimen bisa tertangkap. Kemudian sampel benthik dalam jaring Surber diambil dan dimasukkan ke dalam botol sampel dan diawetkan dengan $20 \mathrm{cc}$ alkohol 70\%. Sampel benthik tersebut dibawa ke Laboratorium Ekologi dan Konservasi Fakultas Biologi Universitas Gadjah Mada dan diidentifikasi sampai pada tingkat genus (Stehr 1987; Stehr 1991; Hawking dan Smith 1977; Quiqly 1977).

\section{Sampel Kualitas Air dan Sedimen}

Pada setiap segmen parameter kualitas air insitu diukur meliputi kecepatan arus air dengan menggunakan bola ping pong, kadar DO dan alkalinitas dengan metode Micro Winkler yang dimodifikasi dari Kit Lamotte, turbiditas dan suhu. Untuk kualitas hara air dan sedimen pada setiap segmen, sampel berupa sampel komposit dari 5 titik sampling. Pengukuran kandungan hara air $\mathrm{NO}_{3^{\prime}} \mathrm{NH}_{4^{\prime}} \mathrm{PO}_{4^{\prime}}$ menggunakan metode analisis kolorimetri. Analisis kandungan $\mathrm{PO}_{4}$ dilakukan dengan metode Bray, dan 

ARIEFIENDY HUSEN, RANI ASMARAYANI, DAN WINA NARULITA RESPON KOMUNITAS ...

C-organik dengan metode analisis kuantitatif volumetris oxydimetris Walkley dan Black. Penentuan kandungan $\mathrm{NO}_{3}$ dan $\mathrm{NH}_{4}$ dengan metode analisis kolorimetri. Parameter kualitas hara air dianalisis di Laboratorium Kimia Analitik Fakultas MIPA UGM. Analisis parameter kualitas hara sedimen dilakukan di Laboratorium Tanah, Fakultas Geografi UGM.

\section{Analisis Data}

Data dari lapangan dan hasil laboratorium ditabulasi, kemudian dihitung parameter densitas, densitas relatif, frekuensi, frekuensi relatif, dan nilai penting. Kemudian hasil perhitungan disajikan dalam bentuk grafik dan tabel berdasarkan lokasi segmen kajian per $0,25 \mathrm{~m}^{3}$ dan kemelimpahan total seluruh segmen dalam $1 \mathrm{~m}^{3}$. Pengelompokan data benthik insekta dipilah dalam fungsional grup. Kemudian data dari segmen kajian tersebut dibandingkan dengan menggunakan indeks Similaritas Sorensen.

\section{HASIL DAN PEMBAHASAN Kehadiran Fungsional Grup Komunitas Benthik}

Hasil penelitian mengungkap bahwa komunitas benthik insekta yang ditemukan di aliran hulu Kali Boyong terdiri atas empat fungsional grup. Keempat fungsional grup benthik tersebut adalah komunitas collector gather, collector filter-feeder, predator, dan scrapper. Akan tetapi, komunitas fungsional shredder tidak ditemukan di sini. Ketidakhadiran fungsional grup shredder menunjukkan bahwa empat bulan pasca kebakaran hutan, kondisi hutan belum pulih. Keadaan ini dicirikan oleh melimpahnya fumgsional grup dominan colector sebesar 2256 individu/ $\mathrm{m}^{3}$ atau $86,02 \%$ dari total kemelimpahan benthik insekta. Fungsional grup collectors yang paling dominan dan memiliki peran yang sangat strategis dalam tingkat trofik di komunitas hulu Kali Boyong. Komunitas collectors yang dominan adalah collector gathers sebesar 1933 individu $/ \mathrm{m}^{3}$ atau $74 \%$ dari total kemelimpahan benthik insekta, sedangkan collector filter-feeder hanya 322 individu/ $\mathrm{m}^{3}$ atau 14\% (Gambar 3 dan Gambar 4).

Fungsional grup collectors gather melimpah pada setiap segmen dari arah hulu ke hilir. Kemelimpahan collector gather pada Segmen I adalah yang tertinggi yaitu sebesar 800 individu/ 0,25 $\mathrm{m}^{3}$. Sedangkan ketiga Segmen berikutnya kehadiran kemelimpahannya berkisar di antara 344-400 individu/ 0,25 $\mathrm{m}^{3}$. Artinya kehadiran collector gathers yang melimpah ini mencerminkan bahwa pakan dominan yang tersedia adalah bukan detritus CPOM, tetapi detritus dalam bentuk FPOM yang ukurannya mendekati 1 $\mathrm{mm}$.

Setelah hutan terbakar, sisa tumbuhan yang terbakar tidak semuanya menjadi abu, tapi ada yang berbentuk partikel CPOM yang berkisar di antara $1 \mathrm{~mm}$. Seperti telah dibicarakan sebelumnya, Ward (1992) melaporkan bahwa colector gathers juga memakan sisa metabolisme shredders. Sisa tersebut berupa FPOM yang berukuran lebih kecil dari $1 \mathrm{~mm}$, tetapi kadangkala komunitas benthik collectors juga memakan CPOM. Fungsional grup shredder tidak ditemukan di hulu Kali Boyong, maka ada CPOM sisa kebakaran yang ukurannya berkisar $1 \mathrm{~mm}$ terutama di Segmen 1. Hal ini dicerminkan oleh melimpahnya genus Baetis di Segmen I sebesar 756 individu individu/ $\mathrm{m}^{3}$ (Gambar 3). Di hulu Kali Boyong, collector gather mempunyai nilai penting paling tinggi di antara segmen kajian, berkisar antara $108-124 \%$, sedangkan nilai penting untuk fungsional grup collector filter berkisar antara $84-99 \%$. Kedua fungsional grup ini mendominasi hulu Kali Boyong empat bulan pasca kebakaran hutan.

Kehadiran fungsional grup predator tidak melimpah, hanya 256 individu/ $\mathrm{m}^{3}$ atau $10 \%$ total kemelimpahan komunitas bentik insekta, sedangkan fungsional grup 
scrapper kemelimpahannya hampir sama dengan predator yaitu hanya 111 individu $/ \mathrm{m}^{3}$ atau hanya $4 \%$ dari total komunitas benthik insekta dari seluruh segmen. Demikian juga dengan nilai penting untuk fungsional grup predators per-segmen kajian adalah sangat rendah yaitu antara $6-47 \%$. Hal yang sama juga ditemukan pada scrapper, nilai pentingnya antara 8-10\%. Rendahnya kemelimpahan fungsional grup scrapper karena pasca-kebakaran kanopi pohon riparian Kali Boyong tidak ada, jadi penetrasi cahaya $100 \%$ masuk ke dalam kali tersebut. Komunitas attach algae menyenangi habitat hulu sungai berbatu dengan tutupan kanopi kiri-kanan sungai yang saling mengunci (interlock) (Gambar 3 dan Gambar 4).

\section{Kekayaan Genus}

Komunitas benthik insekta yang hadir di seluruh aliran segmen hulu Kali Boyong hanya 12 genus (Gambar 3). Bentik collector gathers ditemukan sebanyak 4 genus, yaitu Baetis, Chironomus, Acroperla, dan Atrichopogon. Genus Baetis merupakan genus dominan dan kehadirannya di sepanjang aliran kali mulai Segmen I -IV masingmasing berturut-turut 756 ; 333; 333; dan 333 individu/0,25 $\mathrm{m}^{3}$. Densitas absolutnya yang paling tinggi adalah di aliran kali Segmen I. Hal ini mencerminkan bahwa allochtonous CPOM yang masuk ke aliran Segmen I paling banyak, dan makin ke hilir jumlahnya makin sedikit. Jadi keadaan ini juga mencerminkan adanya hubungan antara genus tersebut dalam mengambil makanannya, dan juga melepas hasil metabolismenya berupa baik CPOM maupun FPOM di sepanjang aliran sungai dalam mata rantai makanan berbasis detritus. Oleh karenanya dapat dikatakan bahwa di hulu Kali Boyong pasca kebakaran hutan mencerminkan komunitas benthik insekta merespon pada pakan detritus allochtonus baik CPOM maupun FPOM yang masuk ke perairan hulu kali tersebut. Kehadiran collector dalam jumlah besar ini mencerminkan bahwa kondisi hutan tangkapan air masih rusak.

Komunitas benthik collector-filter feeder ditemukan sebanyak 3 genus, yaitu Hydropsyche, Agapetus, dan Leuctra. Genus Leuctra merupakan genus dominan, densitas totalnya adalah 166 individu/ $\mathrm{m}^{3}$. Kehadirannya pada masing pada segmen kajian sepanjang aliran kali dengan densitas absolut sebagi berikut 56; 67; 22; dan 22 individu/0,25 $\mathrm{m}^{3}$ Komunitas fungsional grup predator juga ditemukan di hulu Kali Boyong yang memiliki 3 genus, yaitu Dysticus, Eretes, dan juga genus dari famili Odonata. Kehadirannya tidak begitu besar, densitas absolut per segmen berkisar diantara 1189 individu/0,25 $\mathrm{m}^{3}$. Fungsional grup lain yang ditemukan adalah scrapper dengan 2 genusnya, yaitu Atalophlebia dan Nousia, dan kehadirannya dalam aliran air kali berkisar diantara 2 - 4 individu/0,25 $\mathrm{m}^{3}$.

Struktur komunitas bentik insekta yang terbentuk di hulu Kali Boyong sangat berhubungan dengan faktor-faktor yang terjadi di habitat hutan tangkapan airnya. Kebakaran hutan dan curah hujan yang tinggi sangat mempengaruhi kemelimpahan larva akuatik insekta yang terdapat di hulu Kali Boyong. Seperti yang telah dibicarakan sebelumnya, ekosistem hutan daerah tangkapan air Kali Boyong pernah mengalami kebakaran yaitu pada November 1994 dan Oktober 2002. Kebakaran ini memberikan kontribusi hara yang sangat besar merupakan partikel organik allochtonous hasil kebakaran berupa partikel ukuran besar sebagai FPOM maupun ukuran kecil sebagai FPOM. Kebakaran tersebut telah menghancurkan serasah daun ataupun dahan tanaman menjadi partikel-partikel organik berukuran $<1 \mathrm{~mm}$. Komunitas benthik insekta di hulu Kali Boyong telah merespon pada kebakaran tersebut dan hulu Kali tersebut didominasi oleh fungsional grup Collector gathers dan Collector filter feeders. 


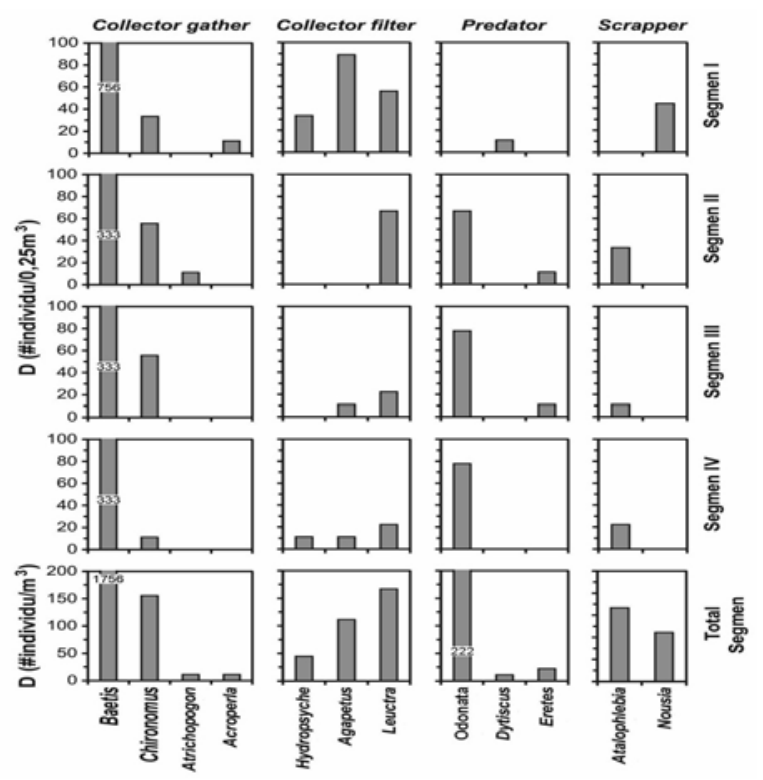

Gambar 3

Densitas Absolut Tiap Genus Penyusun Komunitas Benthik Insekta di Aliran Kali Boyong. dari Segmen I sampai dengan Segmen IV

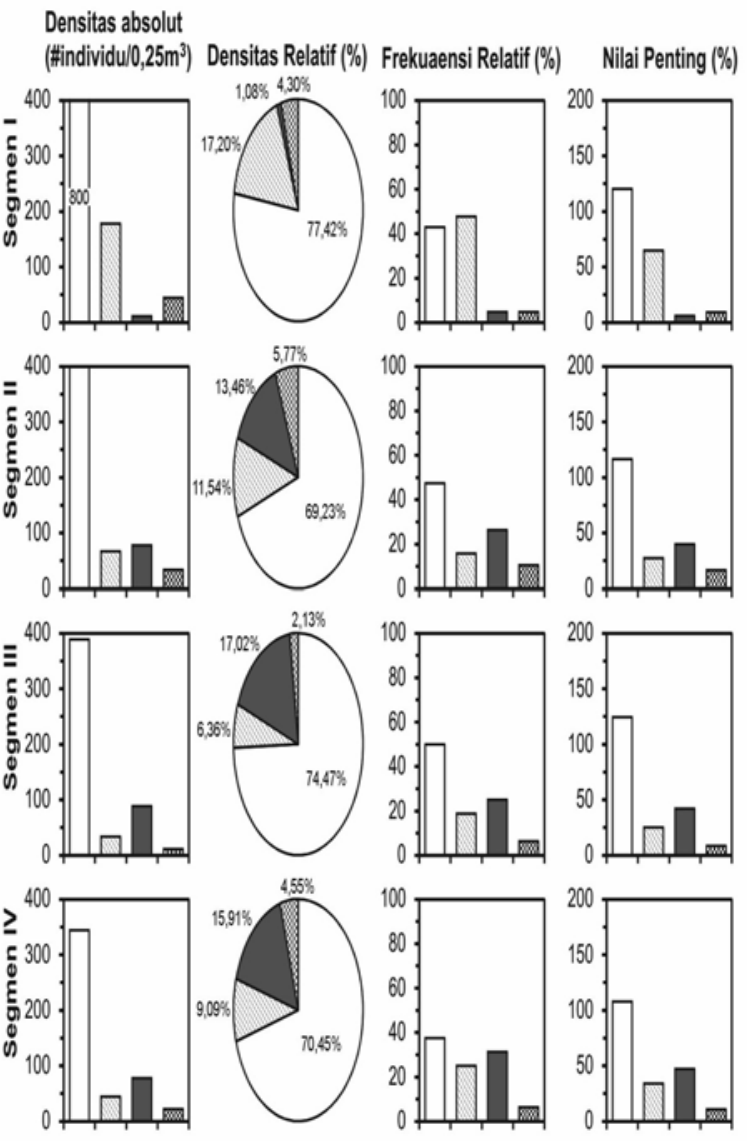

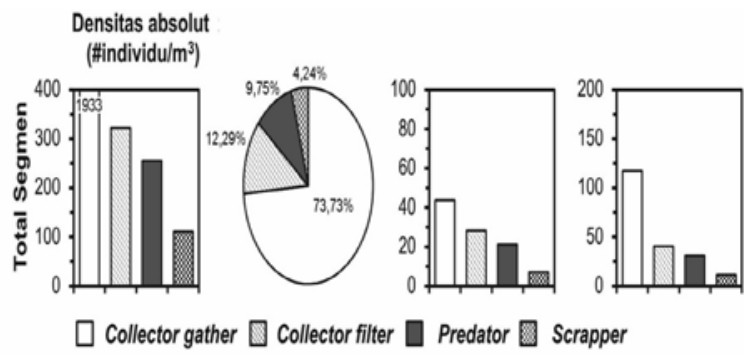

Gambar 4

Densitas Relatif, Frekuensi Relatif, dan Nilai Penting dari Masing-Masing Fungsionak Grup Benthik Insekta di Aliran Kali Boyong.Segmen I - IV

Hasil analisis kandungan hara dalam air dan sedimen yang terdapat di hulu Kali Boyong menunjukkan bahwa pada sedimen sungai terdapat kandungan $\mathrm{NH}_{4}, \mathrm{NO}_{3^{\prime}}$, dan $\mathrm{PO}_{4}$ yang cukup tinggi, kecuali kadar C-organik sedimen yang sangat rendah. Kandungan hara yang terdapat dalam air adalah $\mathrm{NO}_{3}, \mathrm{PO}_{4}$ dan C-organik. Sedangkan untuk $\mathrm{NH}_{4}$ tidak terdapat dalam air karena $\mathrm{NH}_{4}$ hanya terdapat dalam sedimen yang bersifat anaerob. Unsurunsur hara ini kemudian diserap oleh benthik insekta untuk mendukung proses metabolisme dalam tubuh benthik tersebut. Disamping itu, juga berperan untuk pembentukan asamasam amino, dan selanjutnya berperan dalam pembentukan protein dan DNA benthik insekta tersebut (Gambar 5).

Unsur-unsur hara yang terdapat di daerah aliran sungai dibawa oleh air hujan dan masuk ke dalam kali. Curah hujan memberikan pengaruh yang besar terhadap kemelimpahan benthik insekta. Hujan membawa unsur hara yang terdapat di daerah aliran sungai masuk ke dalam sungai, sehingga di dalam sungai baik dalam sedimen maupun dalam air mengandung banyak hara. Akan tetapi, hara tersebut akan terkikis dan terbawa oleh arus air ke hilir. Air hujan juga memberikan pengaruh pada keberadaan benthik insekta dalam kali. Semakin tinggi curah hujan menyebabkan arus air akan tinggi, sehingga dengan sendirinya banyak benthik insekta hanyut terbawa oleh arus air ke hilir. 
Empat bulan pasca kebakaran hutan di hulu Kali Boyong, fungsional grup shredder masih belum ditemukan. Hal ini disebabkan karena tidak tersedianya sumber makanan yang cukup bagi fungsional grup shredder. Seperti diketahui jika shredder merupakan jenis benthik insekta yang memakan dedaunan atau bagian tumbuhan lainnya yang masuk ke dalam sungai. Akan tetapi, di hulu Kali Boyong tidak ditemukan adanya dedaunan atau bagian tumbuhan lain yang masuk ke dalam kali, meskipun daerah sekitarnya merupakan hutan yang tersisa. Hal ini disebabkan karena morfologi Kali Boyong tersebut yang mempunyai badan sungai yang lebar, tetapi permukaan aliran airnya sempit.

Djohan dkk. (2012) melaporkan hal yang sama juga terjadi di hulu Kali Kuning delapan bulan pasca kebakaran hutan tahun 2010, di hulu kali tersebut juga tidak ditemukan benthik insekta shredder. Seperti yang terlihat pada Gambar 1, lebar badan Kali Boyong bagian hulu adalah $36 \mathrm{~m}$, tengah I adalah $32 \mathrm{~m}$, tengah II adalah $36 \mathrm{~m}$, sedangkan lebar hilir adalah 37,5 m. Akan tetapi, lebar permukaan kali yang dialiri air adalah sangat kecil yaitu rata-rata lebarnya hanya $1,5 \mathrm{~m}$. Hal ini menyebabkan dedaunan ataupun bagian tumbuhan lain yang berasal dari daerah aliran sungai tidak dapat masuk ke dalam kali tersebut, dan meskipun ada yang masuk tetapi jumlahnya sangat kecil, sehingga tidak dapat memberikan pengaruh terhadap kehidupan shredder. Selain itu, ketersedian tempat hidup, tempat berlindung dari predator, dan tempat berkembang biak, juga mempengaruhi kemelimpahan benthik insekta di hulu Kali Boyong.
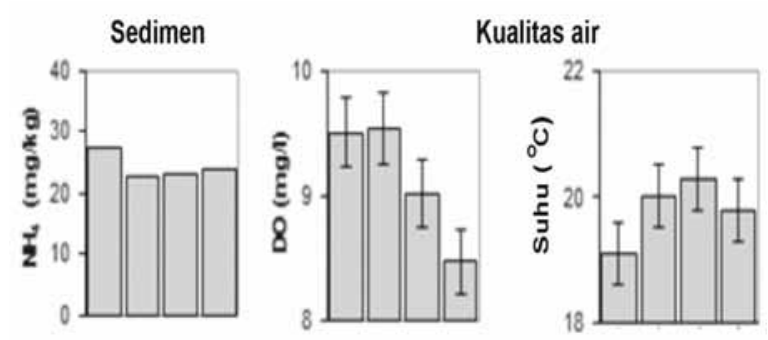
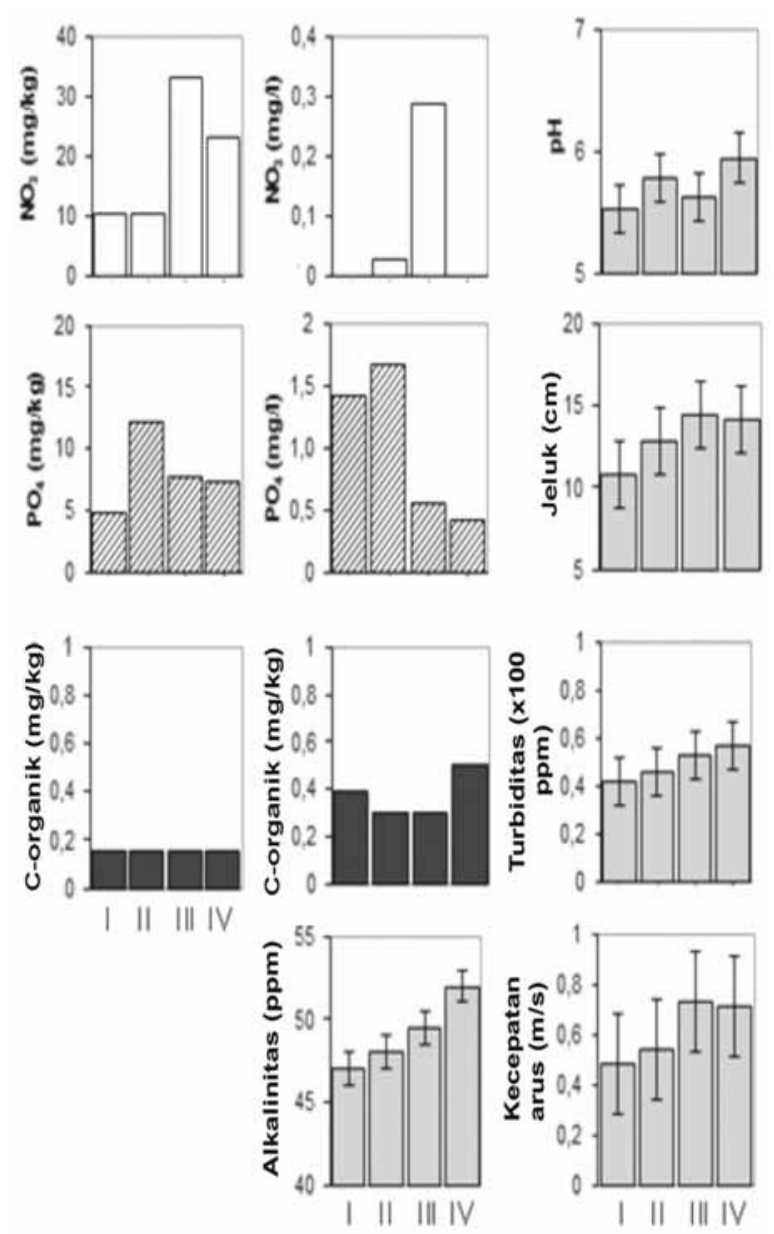

Gambar 5

Kualitas Fisik-Kimia Air dan Kualitas Kimia Sedimen di Hulu Kali Boyong

Benthik insekta umumnya hidup di bawah atau di sela-sela bebatuan. Semakin banyak bebatuan krikil dan ke-rakal (gravel), maka akan semakin baik untuk tempat hidupnya. Kondisi hulu Kali Boyong sangat baik bagi tempat berlindungnya benthik insekta fungsional grup collector dari serangan predator. Hasil penelitian juga menunjukkan bahwa persentase penutupan sungai oleh bebatuan mencapai $80 \%$, sedangkan pasir hanya 20\% (Gambar 6).

Kondisi seperti ini memberikan suatu kelebihan tersendiri bagi kehidupan benthik insekta untuk fungsional grup collectors. Jadi tidak mengherankan bila kemelimpahan benthik insekta fungsional grup collectors sangat dominan di hulu Kali Boyong. 
Bebatuan yang ada di dalam kali tersebut adalah tempat hidup dan mencari makan bagi benthik insekta pemakan berbagai jenis algae yang hidup di bebatuan seperti fungsional grup benthik scrapper. Dengan demikian, benthik insekta genus scrapper juga dapat ditemukan di hulu Kali Boyong meskipun persentasenya lebih rendah daripada collector.
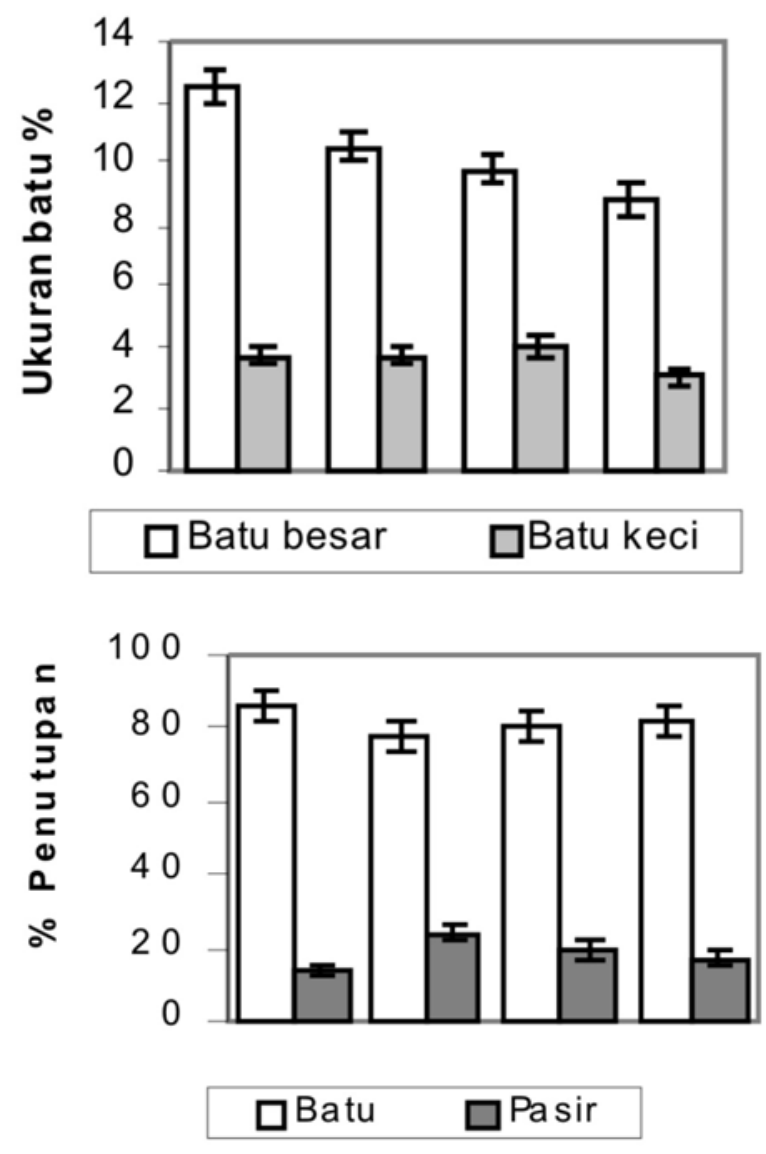

Gambar 6
Prosentase Penutupan Kali Boyong oleh Batu dan Pasir

Segmen-segmen hulu Kali Boyong yang diteliti mempunyai kesamaan komunitas penyusun benthik insekta hulu sungai tersebut. Hal ini dapat dilihat dari nilai indeks similaritas antar segmen di sepanjang aliran kali yang dikaji. Nilai indeks similaritas dan indeks dissimilaritas menunjukkan bahwa ada kesamaan komponen penyusun komunitas benthik insekta di hulu Kali
Boyong. Nilai indeks similaritasnya ratarata di atas $70 \%$. Berarti komunitas benthik insekta relatif sama di antara segmen sepanjang aliran kali di hulu Kali Boyong tersebut. Artinya komunitas fungsional grup benthik insekta tersebut dapat dikatakan sebagai suatu komunitas yang sama (Tabel $1)$.

Tabel 1

Nilai Indeks Similaritas dan Dissimilaritas Sorenson antarSegmen Kajian Sepanjang Aliran Hulu Kali Boyong

\begin{tabular}{|c|c|c|c|c|c|}
\hline & \multicolumn{5}{|c|}{ Indeks similaritas } \\
\hline \multirow{5}{*}{ 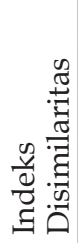 } & Segmen & I & II & III & IV \\
\hline & I & $x$ & 61,33 & 68,87 & 69,77 \\
\hline & II & 38,67 & $x$ & 86,25 & 77,8 \\
\hline & III & 31,13 & 13,75 & $x$ & 85,4 \\
\hline & IV & 30,23 & 22,2 & 14,6 & $x$ \\
\hline
\end{tabular}

\section{SIMPULAN}

Komunitas benthik insekta hulu Kali Boyong merespon kondisi ekosistem hutan tangkapan air di hulu Kali Boyong. Kondisi hutannya masih belum pulih, dicirikan dengan ketidakhadirannya fungsional grup shredder dan adanya dominasi oleh fungsional grup collector yang merespon kepada input allochtonous FPOM. Kehadiran benthik insekta berupa collectors dan shredders dapat digunakan sebagai bio-indikator kesehatan ekosistem hutan daerah tangkapan air. Konsep River Continum Concept (RCC) berlaku juga di sungai hutan hujan tropika.

\section{Ucapan terimakasih}

Kami mengucapkan terimakasih kepada Krisni Suhesthiningsih, M.Sc. untuk diskusinya yang benilai, dan juga untuk anonymous reviewer. Terimakasih juga disampaikan kepada teknisi Laboratorium Ekologi dan Konservasi Fakultas Biologi UGM bapak Suyono yang telah membantu menyiapkan perlengkapan ke lapangan dan di Laboratorium. Terimakasih juga untuk teknisi Laboratorium Tanah Fakultas Geografi UGM dan Laboratorium Kimia 
Analitik Fakultas MIPA UGM yang telah membantu analisis sampel tanah dan air.

\section{DAFTAR PUSTAKA}

Cushing. E.C., G. W. Minshall., dan J. D. Newbold (1993) “Transport dynamics of fine particulate organic matter in two Idaho streams". Limnology and Oceanography, 38: 110-1115.

DeBano, L. F., Neary, D.G., dan Ffliot, P.F. (1998) Fire's effects on ecosystems. John Wiley and Sons, Inc.

Djohan, T. S., K. Suhesthiningsih, dan L. O. M. Erif (2012) Kemelimphan benthik insekta di hulu sungai lereng selatan Merapi pascaerupsi 2010: Indikator kesehatan hutan daerah tangkapan air. Hal. 469-482. Dalam Hartono, S. Purwono, H. Nugroho, S. S.Hariadi, Sudarmaji, dan W. Siswomihardjo. Reviewer. Merapi dalam kajian multidisiplin. Yogyakarta: Sekolah Pascasarjana UGM.

Hawking, J. H., dan F. J. Smith (1977) Color guide to invertebrate of Australia in inland water. Albury: Cooperative Risearch Center for Freshwater Ecology.

Goldman, C.R., dan A.J. Horne (1983) Limnology. New York: Mc Graw Hill Book Co.
Mellon, C. D., M. S. Wipfli, dan J. L. Lie (2008) "Effects of forest fire on headwater stream microin vertebtrate communities in eastern Washington, USA". Freshwater biology 53: 2331-2343.

Minshall, G. W. (2003) "Responses of stream benthic microinvertebrates to fire". Forest Ecology and Management 178: 155-161.

Quiqly. M. (1977). Invertebrata of stream and river a key to identification. London: Edward Arnold.

Spencer, C.N., K.O. Gabel, dan F. R. Hauer. (2003) "Wildfire effects on stream food webs and nutrient dynamics in Glacier National Park, USA". For. Ecol. and Manag. 178: 141-153.

Stehr, F. W. (1987) Immature Insects Vol. I. Kendull/Hunt. Iowa: Publh. Co.

(1991. Immature Insects Vol. II. Kendull/Hunt. Iowa: Publh. Co.

Vannote, R. L., G. M. Minshall, K. W. Cummins, J. R. Sidel, and C. E. Cushing (1980) "The river continuum concept". Can. J. Fish. Aquat. Sci. 37:130137.

Ward, J.V. (1992) Aquatic insect ecology biology and habitat. Vo 1. John Wiley and Sons, Inc.

Wetzel, R. C., and G. Likens (1991) Limnology analysis. $2^{\text {nd }}$ ed. New York: Springer Ferlag. 